\title{
The Determinants of Business Performance of Estate Agency in England and Wales
}

Qiulin Ke

Nottingham Trent University, School of Architecture, Design and Built Environment, Burton Street, Nottingham, UK, NG1 4BU

Email: qiulin.ke@ntu.ac.uk

Tel: 44 (0)115 8482381

Fax: 44(0)115 8486140

David Isaac

The University of Greenwich, School of Architecture and Construction, Avery Hill Campus, Bexley Road, Eltham, London, UK, SE9 2PQ

Email: d.isaac@gre.ac.uk

Peter Dalton

The University of Greenwich, School of Architecture and Construction, Avery Hill Campus, Bexley Road, Eltham, London, UK, SE9 2PQ

\begin{abstract}
Purpose - This paper investigates the factors influencing the business performance of estate agency in England and Wales.

Design/methodology/approach - The paper investigates the effect of housing market, company size and pricing policy on business performance in estate agency sector in England and Wales. The analysis uses the survey data of `Woolwich Cost of Moving Survey' (a survey of transactions costs sponsored by the Woolwich/Barclays Bank) from 2003 to 2005 to test the hypothesis that the business performance of estate agency is affected by industry characteristics and firm factors.

Findings - The empirical analysis indicates that the business performance of estate agency is subject to market environment volatility such as market uncertainty, housing market liquidity and house price changes. The firm factors such as firm size and the level of agency fee have no explanatory power in explaining business performance. The level of agency fee is positively associated with firm size, market environment and liquidity.
\end{abstract}

Research limitations/implication - The research is limited to the data received based on a research project on transaction costs designed prior to this analysis. 
Originality/value - There is little other research that investigates the factors determining the business performance of estate agency, using consecutive data of three years across England and Wales. The findings are useful for practitioners and/ or managers to allocate resources and adjust their business strategy to enhance business performance in estate agency sector.

Key words - Estate agency, Business performance, Determining factors

Paper type - Research paper

\section{The Determinants of Business Performance of Estate Agency in England and Wales}

\section{Introduction}

Estate agents are key intermediaries in transactions between housing buyers and sellers and play a key role in the UK residential property market. The common practice of agents is to charge a fee for the services that is, in most cases, a percentage of the selling price. Agents thus receive commission on sales, which is a prime motivator for them to conclude sales. However, the approach is not usually universally applied and there are some differences at the lower and upper ends of the housing market. In the former case, a minimum fixed fee is usually charged and the information received from this survey shows that some agents usually charge a fixed fee for the properties priced below $£ 100,000$ to cover their costs. For properties at the upper end of the range, for example for the property priced above $£ 750,000$, fees are usually negotiable between agents and vendors. In addition, some agents charge a small fixed element in addition to the percentage of the sale price, this is called a 
mixed fee and is intended to cover costs such as advertising and to help share the risk and uncertainty of the selling process, as there are many stages where negotiations may fail or participants may withdraw from the transaction.

Estate agents provide service products and share many characteristics of the service industry. Manufacturing products are typically mass-produced and have obvious physical characteristics that can be examined prior to purchase. However, services may be intangible in nature, specific to individual consumers and difficult to examine prior to purchase (Shostack, 1997; Zeithaml, 1981). During the process of a housing transaction, estate agents perform a variety of functions which reduce the cost of selling and buying. From the seller's point of view, an agent is usually appointed to value and market the property on their behalf, provide information to potential buyers and negotiate the details of the sale (Miceli et al., 2000). From the buyer's point of view, the agents provide a source of information on available properties. The buyers pay no fee for using the agents as a source of information; the agents are paid by the sellers for their services. Therefore, estate agency is a good example of an intangible dominant industry (Crozier and McLean, 1997). However, housing is a heterogeneous product and its price is affected by a variety of factors. Housing is a valuable asset and the transaction costs involve not just searching for the information about the property but also obtaining property rights and ensuring those rights are sufficient. Thus, property purchasing tends to be infrequent and is subject to high levels of market uncertainty. Since the agency fee is linked to the actual disposal price, the business performance of estate agency is determined by the local property market. 
Another characteristic of the estate agency sector is that it has relatively low barriers to entry (Bishop, 1993; Dietrich and Holmes, 1991; Hallet and Bishop, 1990). Estate agents require no professional qualifications; there are few rules about who can set up such a business. Similarly, it is relatively easy to exit the industry without having to scrap or sell major physical investments. This may go some way to explaining the industry’s reputation in some quarters (Bishop, 2004).

Most of the existing literature on estate agency is limited to an analysis of small subregional markets or case studies of individual firms (e.g. Hallet and Bishop, 1990; Findlay and Gibb, 1998; Milbourne, 1999). The notable studies of estate agency include Crozier and McLean (1997) who relate strategy to buyer behaviour, Hodgkinson (1997) who discusses cognitive inertia and Dietrich and Holmes (1991) who examine the barriers to entry into the estate agency industry. Bishop and Megicks (2002) examine the relationship between competitive strategy and firm size in the UK estate agency sector. Bishop (2004) also examines the reputation of estate agents in the context of principle-agent theory. There have been limited systematic studies of the factors influencing the business performance of estate agency based on a large database and integration of the industry characteristics into the research within the industry.

The generic management theory suggests that the profitability of a firm will be affected by both efficiency of management and external factors such as the state of economy and market competition; the business performance is a complex and multidimensional phenomenon (e.g. Dvir et al., 1993; Carton and Hofer, 2005). The multidimensional concept of business performance comprises effectiveness, 
efficiency and adaptability (Walker and Ruekert, 1987). Effectiveness is the success of a business's product and programme in relation to those of its competitors in the market. Efficiency is considered to be the realised outcomes of a business programme in relation to the resources employed in order to complete them. Finally, adaptability is the level of business success in responding over time to changing conditions and opportunities in the environment.

This paper examines the factors influencing the business performance of estate agency in England and Wales in terms of effectiveness, efficiency and adaptability, using empirical survey data. The study aims to contribute to the understanding of the determinants of economic performance in estate agency sector. The research findings are potentially useful in understanding the factors impacting on the business performance of estate agency and will serve as guidance for practitioners and managers of institutions to allocate resources and adjust their strategy to enhance business performance.

The paper is designed as follows: Section 2 introduces the 'Cost of Moving Survey'. Section 3 reviews literature and defines the study variables. Section 4 analyses the statistical results and Section 5 discusses the conclusions and limitations.

\section{The 'Cost of Moving Survey'}

The 'Woolwich Cost of Moving Survey’ is an annual survey carried out since 1987. The survey looks at the cost of moving within the housing markets. The aims of the survey are to assist in the understanding of the market and to assess the actual costs of moving for budgetary cost purposes. The survey is carried out by the University of 
Greenwich in conjunction with Woolwich/Barclays Bank. Each year, questionnaires are sent to a random sample of estate agents across the UK. Respondents from previous years would receive the questionnaire in the following year and the sample population would be added to in the following year's survey.

Besides the purchase price of the property there are additional transaction costs which need to be factored into a purchaser's budget. Some costs relate to fees for services performed as part of the transaction, such as agency fee, and other costs, such as taxes and legal fees, related to changes of ownership and disposal. The 'Cost of Moving Survey' is based on questionnaires which are circulated to the businesses involved in the exercise of moving - estate agents, solicitors and removal companies.

In this paper, we focus on the study of estate agents in England and Wales. The study period covers three years, using the data from 2003 to 2005, to enable consistency of questions on the questionnaire for the convenience of analysis. Over the three-year period, 11,700 questionnaires were sent out and the average response rate was 19.33\%, providing a large database for analysis.

In the survey, England is segmented into 9 regions. The breakdown of the respondents across England and Wales is reported in Table I. Among the respondents, there are 1,018 (42\%) of agents who responded more than once over the three years, providing consistent and valuable information for the studies.

Table I. Breakdown of respondents in England and Wales

\begin{tabular}{|c|c|c|c|c|c|c|c|c|c|c|}
\hline $\mathrm{N}=2442$ & $\begin{array}{l}\text { East } \\
\text { Anglia }\end{array}$ & $\begin{array}{l}\text { East } \\
\text { Midlands } \\
\end{array}$ & $\begin{array}{l}\text { Greater } \\
\text { London }\end{array}$ & North & $\begin{array}{l}\text { North } \\
\text { West }\end{array}$ & $\begin{array}{l}\text { South } \\
\text { East }\end{array}$ & $\begin{array}{l}\text { South } \\
\text { West }\end{array}$ & Tales & $\begin{array}{l}\text { West } \\
\text { Midlands }\end{array}$ & $\begin{array}{l}\text { Yorks } \\
\text { \&Humber }\end{array}$ \\
\hline Respondents & $6 \%$ & $6 \%$ & $10 \%$ & $5 \%$ & $6 \%$ & $30 \%$ & $20 \%$ & $6 \%$ & $7 \%$ & $6 \%$ \\
\hline
\end{tabular}




\section{Literature review and definition of study variables}

Since 1960s, two major themes have emerged in research on profitability differences among firms - the industrial organization approach and the resource-based theory of the firm. The central argument was that the structural characteristics of industries were the primary determinants of performance (Porter, 1998). The structural characteristics of an industry inevitably constrained the behaviour (i.e. the conduct or strategies) of its component firms, which in turn led to industry-specific performance differentials between firms (Mason, 1939). In this framework, the industry structure in which a firm operates is the main driver of performance variations (e.g. Hoskisson et al., 1999; Bowman and Helfat, 2001). The firm's performance is believed to be determined primarily by a range of the industry's structural characteristics, including economies of scale, barriers to market entry, diversification, product differentiation and the degree of concentration of the firms in the industry (Seth and Thomas, 1994).

In the 1980s, the industry organization studies were challenged by the resource-based view of the firm mainly because of the inability of the industrial organization tradition to provide a rigorous explanation for intra-industry heterogeneity in performance. Resource-based theory stresses the importance of internal resources and the capabilities of the firm to contest in a competitive environment (Collis and Montgomery, 1995). If firms within an industry faced identical conditions of supply and demand and operated under the same market structure, then why did some firms within the same industry still perform better than others? According to resourcebased model, differences in firms' performances across time are due primarily to their unique resources and capabilities rather than the industry's structural characteristics. Therefore, the resource-based view of the firm suggests capabilities evolve and must 
be managed dynamically in pursuit of firm profitability (Lee et al., 2001; Markides, 1999).

In response to the limits of early research on the industry organization and the resource-based theories, a central empirical question for strategic management has been the relative roles of industry and firm effects on firm performance. Schmalensee’s (1985) study was a first attempt to analyze empirically the contribution of industry and firm factors to overall profitability, followed by Rumelt (1991). There are two streams of studies that have come to dominate the literature. The first one suggests that industry factors playing a central role in determining firm profitability while firm effects are insignificant (e.g. Schmalensee,1985; Montgomery and Porter, 1991; Wernerfelt and Montgomery, 1988 ). The second study, motivated by Rumelt (1991) confirms the dominance of firm-specific effects (e.g. Brush et al. 1999; Hawawini et al. 2003; Mauri and Michaels, 1998; McGahan and Porter, 1997, 2002).

The data used in these previous studies are across industries. One problem is the insufficient classification categories in the system, therefore, the conclusion that firm effects are dominant, are to be interpreted with some caution. As pointed out by Hawawini et al. (2003), if one cannot properly define industries in an economically relevant manner, then estimates of the degree of industry effects on performance, irrespective of how it is measured, will not be completely reliable.

One of the advantages of our research is that we use the data of one sector, that is the residential estate agency sector, so the issue of insufficient classification categories can be avoided. 
Based on the framework of these theories, the hypothesis of the study is that the business performance of estate agency is affected by industry characteristics and organizational factors. To test the hypothesis, the following data have been selected from the questionnaire. The full data at this stage have 2,264 cases covering the three years from 2003 to 2005. The study variables are defined as follows:

- Business performance growth level (Study variable: Growth)

Firm performance may at various times be reflected by financial outcomes, sales or market growth, customer satisfaction or establishing a foundation upon which future growth may take place (Dvir et al., 1993). Previous research shows that sales growth and profitability are contemporaneous and substitutable (Qian and Li, 2003) and they are positively related due to optimal size and efficient scale (Gupta, 1981; Mansfield, 1979). Since the direct data of profitability and costs of the estate agents are not available, the question "the level of business growth in the past twelve months" is used as proxy for business performance. A seven-point Likert-type scale is used, running from 1 to 7 with "Down more than 10\%" indicated as 1 , and "Up more than $10 \%$ ” as 7 , with the following intermediate selections available: "Down 5-9\%”, “Down 0-4\%”, “About the same”, “Up 0-4\%” and “Up 5-9\%”.

- $\quad$ The size of business (Study variable: Size)

The size of estate agency as an organizational factor is represented by the number of outlets in the organization to which a particular office belongs. The empirical studies (e.g. Baldwin, 1998; Bannerjee and Duflo, 2000) have yielded conflicting results about the relation of firm size to firm business performance. For example, Ross (1993) finds that small firms are to some extent more profitable than large firms. He 
explains that large businesses are particularly vulnerable in a changing business environment because of the difficulty in adjusting from a controlled market structure to an atomistic structure. However, increasing the firm size is hypothesised to indicate reduced risk aversion as large companies are better able to bear risk due to their access to a large pool of internal resources (Bannerjee and Duflo, 2000).

Crozier and McLean (1997) state in their survey of estate agency that the customers rate company size as one of the most important influence on the decision-making process of vendors. Bishop and Megicks (2002) state that different types of firm place a greater emphasis upon different strategic positions and conclude that size has some impact upon strategic positions. Bishop (2004) in his study uses firm size as a proxy for the reputation of estate agent and argues that the many large agencies are part of groups with established brand names and are more likely to offer a mixed fee contract (i.e. small fixed fee plus the percentage of sold house price).

To measure firm size, the respondents are asked to detail the number of outlets in their organization. A five-point Likert-type scale approach is adopted running from 1 to 5 with "single practice" indicated as 1 and "more than 20 outlets" as 5 , with the following intermediate selections available: “2-4 outlets”, “5-9 outlets” and “10-20 outlets”.

- Market economic scale (Study variable: Scale):

This is used as industry factor. One of the industry-specific characteristics of estate agency is that the size of housing market has an effect. House prices vary across space within specific housing markets and are also subject to short run price change as local 
markets adjust to exogenous shocks. As agency fees are directly linked to house price, local market conditions will be critical. A firm dealing with large transaction volumes would be likely to enjoy scale economies; whereas, in contrast, cost in thin rural markets may be considerably higher (Findlay and Gibb, 1998). To measure the impact of market economic scale on the business performance, respondents are asked to choose the most active sector in their regions from the different property price bands, with the lowest one of $£ 49,999$ and the highest of $£ 1,000,000$.

- Market liquidity (Study variable: Liquidity).

One of the characteristics of property market is its illiquidity. Buying and selling residential property requires considerable monetary and non-monetary investment on the part of the purchaser and the vendor. Searching and information costs are unusually high in the housing market (Maclennan, 1982). The intrinsic interrelationship of housing market to estate agency suggests that market liquidity should have an impact on the performance of the estate agency sector. To measure market liquidity as an industry factor, respondents are asked to detail the change in the number of new instructions received in the past three months, compared with the normal expectations at the same time of the year. It is hypothesized that the more the new instructions are received, the more liquid the market is, and the better the estate agency performs. A seven-point Likert-type scale approach is used with 1 indicating “Down more than 10\%”, running through to 7 indicating "Up more than 10\%” and 3 indicating “About the same” as a mid-point.

- Agency Fees (Study variable: Fees). 
Fee strategy is regarded as one of the three basic generic business strategies (e.g. Hambrick, 1983; Miller, 1986; Porter, 1998). For example, Yamin et al. (1999) argue that a cost leadership strategy records a significantly higher financial performance and market effectiveness than any other strategies. Generally speaking, it is assumed that margins are low in the estate agency industry (Findlay and Gibb, 1998) and the estate agents are competing with their high street rivals over new business. The literature focusing on the arguments of agency fee strategy includes, for example, Crozier and McLean (1997) who suggest that agencies may secure competitive advantage by differentiating their offering through investing in high quality service provision rather than reducing costs to facilitate charging low fees. Some research links the fees with the reputation of agents (O’Farrell et al., 1993; Bishop, 2004). They argue that a low fee strategy might run the risk of compromising the reputation that national chains have established in other markets. Regarding the fee's impact on the business, Crozier and McLean (1997, p. 287) note that, although in general, consumers are not overly concerned with the price charged by estate agents, “price may be important to some people”. To investigate the relationship between fee and business performance, the levels of fee charged on the property price bands of $£ 100,000-£ 124,999$ (£100k), $£ 125,000-£ 149,999$ (£125k), £150,000-£199,999 (£150k) and £200,000-£299,999 (£200k) are used as control variables, since these are the active price sectors in residential property market. It is worth mentioning here that the fee levels from the questionnaire are presumed to be nominal fees. The actual fees may depend on the client's ability of negotiation, which no agents would be likely to disclose. This variable is used as organization factor.

- House price (Study variable: Price). 
Agents take a fee as a percentage of the final sale price of the house, which links their income to an important measurable indicator of the house price. This variable is used as industry factor. The pricing behaviour of agents may be connected with the factors such as market competition, housing market and industry regulation; therefore, the performance of agency will be affected by housing market conditions and the housing markets are very localized (Driver, 1984). To take this factor into consideration, the average house prices from Q4, 2003 to Q4, 2005 in each region taken from the Land Registry Residential Property Price Report are used as an extraneous factor to reflect the variation in local house prices.

- $\quad$ The market prospect (Study variable: Prospect).

Existing literature suggests that the business environment is composed of several segments such as client, competitor, economic and regulatory (Fahey and Narayanan, 1986). Thus, the question "Prospects on the business for the following year" is used as a control variable to proxy the changing market environment. A three-point scale approach is used with 1 indicating "less optimistic"; 2 indicating "about the same" and 3 indicating "more optimistic".

- Regions (Study variable: Region).

The housing market is localized. There is some literature of the definition of local housing markets, possible segmentation and the problems of aggregation bias if wrongly measured (MacLennan, et al., 1987; Rothenberg, et al., 1991) which demonstrates the difficulties associated with defining functional boundaries for local housing markets. MacLennan and Tu (1996) argue on grounds of practicality and data availability that local authority boundaries (1995-96 jurisdictions) and multiples 
therefore, are the most sensible way to capture the impact of local variations in house price, turnover and market size. Bearing these problems in mind, we use the jurisdictional boundaries to segment England into 9 regions and the dummy variables are used assuming that East Anglia (EA) equals 1; East Midlands (EM), 2; Greater London (GL), 3; North (N), 4; North West (NW), 5; South East (SE), 6; South West (SW), 7; Wales (W), 8; West Midlands (WM), 9; and Yorks \& Humber (YH), 10. These variables are used as industry factor.

In terms of non-sampling errors, an attempt was made to assess the potential for nonresponse bias in the studies (Frankfort-Nachmias and Nachmias, 1992). The sample is divided into two groups: the agents $(1,019)$ responding more than once in the three years and the agents $(1,133)$ responding once in the three years. Non-respondents can be assessed by testing for any differences in the characteristics of the two groups. This extrapolation approach (Armstrong and Overton, 1977) is based on the assumption that the ones responding once are more likely to be representative of non-respondents than those responding on more than one occasion. An independent sample t-test and the Wilcoxon related sample test are conducted to examine the differences between the two groups of the respondents on the means of each of the constructs. No significant differences were found in the major constructs such as business performance growth level, firm size, market prospect, fees and market liquidity at the level of 5\%. However, the significant difference in market economic scale is found, indicating that the non-respondents are more likely to reap market economic scale measured by the most active house price sector in their regions.

\section{Statistic analysis}


The basic premise of the econometric work is to establish the extent of the relationship, if any, between a measure of business performance of estate agency in England and Wales and a number of independent variables. The data analysis is undertaken by using the SPSS statistics package. Table II presents the descriptive statistics of the study variables.

Table II. Descriptive Statistics of study variables

\begin{tabular}{|c|c|c|c|c|c|c|c|c|c|c|}
\hline \multirow[t]{2}{*}{$N=2,264$} & \multirow[t]{2}{*}{ Growth } & \multirow[t]{2}{*}{ Size } & \multirow[t]{2}{*}{ Prospect } & \multirow[t]{2}{*}{ Liquidity } & \multirow{2}{*}{$\begin{array}{c}\text { Scale } \\
\text { in } £ 10 k \\
\end{array}$} & \multirow{2}{*}{$\begin{array}{r}\text { Price } \\
\text { in } £ 10 \mathrm{k} \\
\end{array}$} & \multicolumn{4}{|c|}{ Fees for price bands } \\
\hline & & & & & & & $£ 100 \mathrm{k}$ & $£ 125 \mathrm{k}$ & $£ 150 \mathrm{k}$ & $£ 200 k$ \\
\hline Mean & 5 & 2 & 2 & 4 & 236 & 186 & 1,498 & 1,850 & 2,197 & 2,885 \\
\hline SD & 2 & 1 & 1 & 2 & 195 & 55 & 394 & 477 & 570 & 782 \\
\hline Min. & 1 & 1 & 1 & 1 & 49 & 61 & 175 & 495 & 495 & 495 \\
\hline Max. & 7 & 5 & 3 & 7 & 349 & 345 & 3,000 & 4,559 & 4,712 & 6,170 \\
\hline
\end{tabular}

The average business growth level in three-year times is $0-4 \%$ represented by the scale of 5 , varying from 1 for "down more than $10 \%$ " to 7 for "up more than $10 \%$ ". The average size of the estate agents is $2-4$ outlets indicated by the scale of 2 , highlighting the importance of the small business in agency market. Market prospect and market liquidity are maintained at about the same level, as indicated by the scales of 2 and 4 respectively, indicating the relatively stable housing market environment and agency industry over the study period. The market economic scale represented by the most active house price sector is $£ 236,000$, falling into the price band of $£ 200,000$ to $£ 299,999$, this, however deviated greatly (with a minimum of $£ 49,999$ and a maximum of $£ 349,999$ across the regions), reflecting the difference in regional markets. The average house price across the regions over the study period is $£ 186,000$, with the minimum of $£ 61,000$ and maximum of $£ 345,000$. The level of fees charged on the selected house price bands is about $1.5 \%$ of the sale price on average. However, the minimum fee of the three selected house price bands is $£ 495$, suggesting 
that some agents charge the fixed fee across different price bands. To test the relation between the variables, the correlation is run and the results are reported in Table III.

Table III. Correlations of study variables

\begin{tabular}{|c|c|c|c|c|c|c|c|c|c|c|c|}
\hline Variables & 1 & 2 & 3 & 4 & 5 & 6 & 7 & 8 & 9 & 10 & 11 \\
\hline 1. Size & 1 & & & & & & & & & & \\
\hline 2. Growth & 0.03 & & & & & & & & & & \\
\hline 3. Prospect & 0.03 & $0.22 * *$ & & & & & & & & & \\
\hline 4. Liquidity & 0.02 & $0.17 * *$ & $0.24^{* *}$ & & & & & & & & \\
\hline 5. Scales & $0.07 * *$ & $-0.08 * *$ & 0.01 & -0.00 & & & & & & & \\
\hline 6. £100k & $0.23^{* *}$ & $-0.09^{* *}$ & 0.02 & -0.03 & $0.24 * *$ & & & & & & \\
\hline 7. £125 & $0.23^{* *}$ & $-0.07^{* *}$ & 0.04 & -0.04 & $0.23^{* *}$ & $0.94 * *$ & & & & & \\
\hline 8. £150k & $0.23 * *$ & $-0.08^{* *}$ & 0.04 & -0.04 & $0.23^{* *}$ & $0.91 * *$ & $0.97 * *$ & & & & \\
\hline 9. $£ 200 \mathrm{k}$ & $0.23 * *$ & $-0.10^{* *}$ & $0.05 *$ & -0.03 & $0.26 * *$ & $0.87 * *$ & $0.93 * *$ & $0.96 * *$ & & & \\
\hline 10. $£ 300$ & $0.25^{* *}$ & $-0.08^{* *}$ & $0.07 * *$ & -0.03 & $0.28 * *$ & $0.82 * *$ & $0.88 * *$ & $0.91^{* *}$ & $0.95^{* *}$ & & \\
\hline 11. Price & $-0.04 *$ & $-0.26 * *$ & -0.003 & -0.04 & $0.38 * *$ & $0.38 * *$ & $0.37 * *$ & $0.38 * *$ & $0.39 * *$ & $0.39 * *$ & \\
\hline
\end{tabular}

The correlations show that the firm size is significantly related with market economic scale and fee levels, indicating that the larger firms may have more resources or capability to handle the transactions with higher value than the smaller firms and at the same time, they charge a higher fee. This may be explained by the fact that dealing property with higher values requires more expertise and effort and bears higher risk. The inverse relation of firm size and house price shows that large firms may be less vulnerable to the impact of house price fluctuations, compared to the small ones. Unexpectedly, the firm size is weakly related to firm performance, market liquidity and market prospect.

To further investigate the impact of the study variables on the business performance of estate agency, the regressions are run. When running the regression analysis, the SPSS system automatically excludes one of regional dummy variables- South East (SE6), since South East weighs 30\% of the total sample and is highly correlated with 
the total sample, resulting in the bias. Table IV presents the regression outcome of the controlling variables on the business performance.

As expected, the significant relationship of business growth level to market prospect, market liquidity, and house price is found, indicating the industry factors determine the business performance of the estate agency in England and Wales, whilst the firm effects are insignificant, consistent with the findings of Schmalensee (1985), Montgomery and Porter (1991), and Wernerfelt and Montgomery (1988). The positive relationship between market prospect and business performance suggests that good understanding of housing market and estate agency industry market is significantly important in improving the business performance. The positive coefficient of market liquidity suggests that the housing market liquidity apparently influences the business performance of the estate agency.

The insignificant coefficients of fees to business performance seem to be consistent with the studies of Crozier and McLean (1997) who argue that the estate agency industry is generally characterised by differentiation strategies rather than price competition. They conclude that the four most important factors influencing consumer choice in estate agency are staff attitude, company reputations, the range of services provided and staff appearance, while low fees are regarded as of much less importance.

The inverse relation of house price to the business performance suggests that rising house prices would reduce the liquidity of housing market; therefore, negatively influencing the business performance of estate agency. Thus, compared with fees, 
market liquidity is a more important factor affecting the business performance of estate agency. The findings are especially useful for managers in agencies who need to adjust strategies to adapt to the changing market.

There is no connection found between firm size and business performance. The coefficient signs of the firm size in Table IV are mixed and insignificant. One issue that should be pointed out is that the firm size refers to the number of branches of the company to which the respondent belongs and the business growth level may refer to that of an individual branch without considering the consolidated growth of the whole company, which might explain the mixed signs of firm size to business growth level. This research is thus constrained by the questions asked in the questionnaire. Discussion about the firm size of estate agency in the literature is mainly related to competitive strategy (Bishop and Megicks, 2002) and reputation (Crozier and McLean, 1997; Bishop, 2004). For example, Bishop (2004) finds that larger firms are more likely to offer mixed contracts (i.e. fixed fee plus the percentage of the sold house price) and suggests that the size of the firm is acting as a proxy for reputation which might have an influence on the profitability of the agency. The finding here does not seem to be consistent with his suggestion and the reason needs to be investigated. Due to the unavailability of data, we could not exploit the issue further in this paper.

The insignificant coefficient of the variable of market economic scale suggests that there is no great cost advantage to large-scale transactions which would eventually influence the business performance. The region dummy variables of North, North West and South West have significant coefficients, suggesting the existence of market 
locality in estate agency industry as in the housing market and the geographic variation in the business performance. The estate agents in North West, South West and Wales performed significantly well over the study period.

To understand the pricing behaviour of estate agents, the regressions of the controlling variables on the fees are conducted and the results are reported in Table V. Here we only tabulate the regression outcomes on the fees charged for the property price bands of $£ 150,000$ and $£ 200,000$, since identical results are found in the equations of price bands of $£ 100,000$ and $£ 300,000$.

The fees are significantly related with firm size. The positive signs show that the larger firms are more likely to charge higher fees than the smaller firms. Such a finding is consistent with the other studies (e.g. Driver, 1984; Dietrich and Holmes, 1991; Bishop and Megicks, 2002). These studies suggest that large firms are competing through positioning their product at the high quality end of the market and by offering a wide range of services and as such are more likely to offer mixed fee contracts (Bishop, 2004). A small firm might be able to secure competitive advantage by offering services of relatively limited scope, focusing on small local niches and offering low fees (Bishop and Megicks, 2002).

The effect of fee levels charged is insignificant on the business growth rate, consistent with the results in Table IV. Crozier and McLean (1997) argue that matching local competitors is the essence of survival in the market. Higher fees will not attract the fee-sensitive customer when other factors such as the quality of services are hard to observe during the process of transaction. 
The significant relationship of market prospect to fees suggests that the fees are likely to rise with the upturn of market. But when the market is less liquid and the number of the new instructions received declines, the agents would not be likely to lower their service fee. This might be explained that when the market turns downsize and/or the transaction volume in housing market declines, the costs may be considerably higher.

Significant coefficients of market liquidity in the two equations suggest that agents are likely to reduce the fees to accelerate the transaction and market liquidity, which will eventually enhance the business performance, as shown in Table IV.

The significant coefficients of regions excluding South East provide strong evidence that there exist market locality and geographic variations in estate agency fees across England and Wales. The fees charged by the agents in East Anglia, Greater London and South West are significantly higher than in other regions.

In sum, the findings here suggest that the industry characteristics have significant power in explaining the business performance of estate agents; whilst the organization factors have insignificant effect. 
Table IV. The regression outcomes on business performance

\begin{tabular}{|c|c|c|c|c|c|c|c|c|c|c|c|c|c|c|c|c|c|c|}
\hline \multirow{3}{*}{$\mathrm{N}=1264$} & \multirow{3}{*}{ Size } & \multirow{3}{*}{ Prospect } & \multirow{3}{*}{ Liquidity } & \multirow{3}{*}{ Scale } & \multirow{3}{*}{ Price } & \multirow{2}{*}{\multicolumn{4}{|c|}{ Fees }} & \multirow{2}{*}{\multicolumn{9}{|c|}{ Regions }} \\
\hline & & & & & & & & & & & & & & & & & & \\
\hline & & & & & & $£ 100 \mathrm{k}$ & $£ 125 \mathrm{k}$ & $£ 150 \mathrm{k}$ & $£ 200 \mathrm{k}$ & $\mathrm{EA}(1)$ & $\operatorname{EM}(2)$ & GL(3) & $\mathrm{N}(4)$ & NW(5) & SW(7) & (8) & $\begin{array}{l}\text { WINI } \\
(9)\end{array}$ & YH (10) \\
\hline & $\begin{array}{c}-0.01 \\
(-0.20)\end{array}$ & $\begin{array}{c}0.46 \\
(6.45)^{* * *}\end{array}$ & $\begin{array}{c}0.18 \\
(5.46)^{* * *}\end{array}$ & $\begin{array}{c}0.00 \\
(-0.52)\end{array}$ & $\begin{array}{c}-0.01 \\
(-3.57)^{* * *}\end{array}$ & $\begin{array}{c}0.00 \\
(1.03)\end{array}$ & $\begin{array}{c}0.00 \\
(-0.21)\end{array}$ & $\begin{array}{c}0.00 \\
(-0.69)\end{array}$ & $\begin{array}{c}0.00 \\
(0.40)\end{array}$ & $\begin{array}{l}-0.40 \\
(-1.56)\end{array}$ & $\begin{array}{c}0.06 \\
(0.42)\end{array}$ & $\begin{array}{l}-0.09 \\
(-1.22)\end{array}$ & $\begin{array}{c}0.07 \\
(0.83)\end{array}$ & $\begin{array}{c}0.10 \\
(1.69)^{* *}\end{array}$ & $\begin{array}{c}0.06 \\
(2.28)^{* * *}\end{array}$ & $\begin{array}{c}0.05 \\
(1.43)^{*}\end{array}$ & $\begin{array}{c}-0.01 \\
(-0.50)\end{array}$ & $\begin{array}{c}0.05 \\
(1.60)\end{array}$ \\
\hline
\end{tabular}

Constant: $4.26(8.45)^{* * *}$

Adjusted $\mathrm{R}^{2}: 1.32$

F: 9.55

P-value: 0.00

Note: $1 . t$-test is in parentheses

2. ${ }^{*} * *$ and ${ }^{* * *}$ represent the significant levels of $10 \%, 5 \%$ and $1 \%$.

Table V. The regression outcomes on agency fee

\begin{tabular}{|c|c|c|c|c|c|c|c|c|c|c|c|c|c|c|c|}
\hline & Growth & Size & Prospect & Liquidity & Scale & Price & $\mathrm{EA}(1)$ & $\operatorname{EM}(2)$ & GL(3) & $N(4)$ & NW(5) & SW(7) & $\mathrm{W}(8)$ & WM(9) & YH (10) \\
\hline $\begin{array}{l}\text { Fee on } \\
£ 150 \mathrm{k}\end{array}$ & $\begin{array}{l}2.55 \\
(0.45)\end{array}$ & $\begin{array}{c}104.20 \\
(12.56)^{* * *}\end{array}$ & $\begin{array}{l}22.64 \\
(1.55)\end{array}$ & $\begin{array}{c}-11.48 \\
(-1.69)^{*}\end{array}$ & $\begin{array}{c}0.24 \\
(4.19)^{* * *}\end{array}$ & $\begin{array}{c}0.00 \\
(0.01)\end{array}$ & $\begin{array}{c}125.78 \\
(2.32)^{* *}\end{array}$ & $\begin{array}{c}-188.55 \\
(-6.56)^{* * *}\end{array}$ & $\begin{array}{c}134.49 \\
(9.72)^{* * *}\end{array}$ & $\begin{array}{c}-165.99 \\
(-9.96)^{* * *}\end{array}$ & $\begin{array}{c}-101.02 \\
(-8.58)^{* * *}\end{array}$ & $\begin{array}{c}19.21 \\
(3.70)^{* * *}\end{array}$ & $\begin{array}{c}-31.71 \\
(-4.17)^{* * *}\end{array}$ & $\begin{array}{c}-49.94 \\
(-9.01)^{* * *}\end{array}$ & $\begin{array}{c}-61.93 \\
(-10.59)^{* * *}\end{array}$ \\
\hline Constant & $\begin{array}{c}1,967.87 \\
(20.73)^{* * *}\end{array}$ & & & & & & & & & & & & & & \\
\hline $\begin{array}{l}\text { Adjusted } \\
\mathrm{R}^{2}: \\
F \\
P \text {-value }\end{array}$ & $\begin{array}{c}0.36 \\
71.15 \\
0.00\end{array}$ & & & & & & & & & & & & & & \\
\hline Fee on & & & & & & & & & & & & & & & \\
\hline$£ 200 \mathrm{k}$ & $\begin{array}{c}-0.18 \\
(-0.02)\end{array}$ & $\begin{array}{c}139.57 \\
(12.64)^{* * *}\end{array}$ & $\begin{array}{c}38.84 \\
(1.97)^{* *}\end{array}$ & $\begin{array}{l}-15.45 \\
(-1.69)^{*}\end{array}$ & $\begin{array}{c}0.38 \\
(5.08)^{* * *}\end{array}$ & $\begin{array}{c}-0.19 \\
(-0.40)\end{array}$ & $\begin{array}{c}177.89 \\
(2.41)^{* *}\end{array}$ & $\begin{array}{c}-241.67 \\
(-6.18)^{* * *}\end{array}$ & $\begin{array}{c}184.40 \\
(10.17)^{* * *}\end{array}$ & $\begin{array}{c}-231.08 \\
(-10.23)^{* * *}\end{array}$ & $\begin{array}{c}-145.53 \\
(-9.13)^{* * *}\end{array}$ & $\begin{array}{c}28.14 \\
(4.03)^{* * *}\end{array}$ & $\begin{array}{c}-55.57 \\
(-5.37)^{* * *}\end{array}$ & $\begin{array}{c}-71.64 \\
(-9.55)^{* * *}\end{array}$ & $\begin{array}{c}-83.84 \\
(-10.60)^{* * *}\end{array}$ \\
\hline Constant & $\begin{array}{c}2,617.06 \\
(20.39)^{* * *}\end{array}$ & & & & & & & & & & & & & & \\
\hline $\begin{array}{l}\text { Adjusted } \\
\mathrm{R}^{2} \text { : }\end{array}$ & 0.37 & & & & & & & & & & & & & & \\
\hline$F$ & 77.12 & & & & & & & & & & & & & & \\
\hline P-value & 0.00 & & & & & & & & & & & & & & \\
\hline
\end{tabular}




\section{Conclusion and limitation}

This paper uses the 'Woolwich Cost of Moving Survey’ data from 2003 to 2005 to analyse the factors influencing the business performance of estate agency in England and Wales. It provides a unique insight into the understanding of the business performance of estate agency industry. The empirical analysis here shows that the business performance of estate agency is subject to the external market environment changes such as house price, market uncertainty and liquidity. The impact of firm size and commission fees on the business performance of estate agency is not significant. The large size of a firm does not mean efficiency. There appears to be geographical variations in the business performance of estate agency across regions in England and Wales. The regions such as North West, South West and Wales perform significantly well over the study period.

By examining the pricing behaviour of estate agents, we find that large firms are more likely to charge a higher fee; but the level of fee has no significant influence on business performance. When the market is less liquid, agents have to raise or maintain the fee level in order to cover the costs. The existence of geographical variations in agency fees is found, reflecting the local nature of the estate agency market. The commission fees charged by the estate agents in East Anglia, Greater London and South West are significantly higher than in other regions.

The empirical study here suggests that in order to improve business performance, managers should be more aware of the external market change and a cost leadership 
strategy without compromising the quality of the service and reputation as business strategy, especially for the larger firms who have a large internal resource pool.

The results presented are contingent on the flaws in the data received and have been discussed at length. They are also contingent on the inherited sampling strategy adopted by the survey designed prior to the study. However, a fairly robust and reasonably well-explained model of the combined factors and business performance has been presented. The result is consistent with the hypothesis of management literature and specific industry character of estate agency.

The limitation of the research is that, first of all, this paper focuses on the analysis of the impact of the external factors such as market prospect and liquidity, house price and market economic scale. There is little analysis of the internal factors such as the management efficiency, organizational strategy and the control of service quality because the information is not included in the survey. This is a gap left for further study. Secondly, the findings here provide evidence of the influence of environment uncertainty on business performance, but it does not explain the measures taken by estate agents to minimise business uncertainty to reduce risk.

\section{References}

Armstrong, J.S. and Overton, T.S. (1977), "Estimating non-response bias in mail surveys”, Journal of Marketing Research, Vol.16, pp. 396-400.

Baldwin, J.R. (1998), "Were small producers the engines of growth in the Canadian manufacturing sector in the 1980s?” Small Business Economics, Vol.10, No. 4, pp. 349-64.

Bannerjee, A.V and Duflo, E. (2000), "Reputation effects and the limits of contracting: a study of the Indian software industry”, Quarterly Journal of Economics, Vol.115, pp. 989-1017. 
Bishop, P. (1993), “The changing structure of estate agency”, Service Industries Journal, Vol.13, pp. 307-316.

Bishop, P. (2004), “Despised, slippery and untrustworthy? An analysis of reputation in estate agency”, Housing Studies, Vol.19, No.1, pp. 21-36.

Bishop, P. and Megicks, P. (2002), "Competitive strategy and firm size in the estate agency industry”, Journal of Small Business and Enterprise Development, Vol. 9 No. 2, pp.150-161.

Bowman, E. H and Helfat, C. E.(2001), “Does corporate strategy matter?” Strategic Management Journal 22(1), pp.1-23.

Brush, T. H., Bromiley, P. and Hendrickx, M. (1999), "The relative influence of industry and corporation on business segment performance: An alternative estimate”, Strategic Management Journal, 20(6), pp. 519-547.

Carton, R.B. and Hofer, C.W. (2005), “Organizational financial performance: identifying and testing multiple dimensions", in Proceedings of the ICSB $50^{\text {th }}$ World Conference-2005.

Collis, D. J. and Montgomery, C. A. (1995), “Competing on Resources: Strategy in the 1990s”, Harvard Business Review, Vol. 73, No. 2, pp.118-128.

Crozier, D.A. and McLean, F. (1997), “Consumer decision-making in the purchase of estate agency services”, Service Industries Journal, Vol.17, pp. 278-93.

Dietrich, M. and Holmes, P. (1991), "Financial institutions and the estate agents industry in the 1980s”, Service Industries Journal, Vol.11, pp. 481-90.

Driver, J. (1984), “Estate agency: a marketing challenge”, Service Industries Journal, Vol. 4, pp. 91-107.

Dvir, D. E., Segev, E. and Shenhar, A. (1993), “Technology’s varying impact in the success of strategic business units within the Miles and Snow typology”, Strategic Management Journal, Vol.14, pp.155-162.

Fahey, L. and Narayanan, V. K. (1986), “Macroenvironmental analysis for strategic management”, Thomson Learning.

Findlay, J. and Gibb, K. (1998), “The pricing of estate agency and conveyancing services in Scotland”, Journal of Property Research, Vol.15, No. 2, pp.135151.

Frankfort-Nachmias, C. and Machmias, D. (1992), Research Methods in the Social Science, $4^{\text {th }}$ ed., Edward Arnold, London.

Gupta, V. K. (1981), “Minimum efficient scale as a determinant of concentration”, 
The Manchester School of Economic \& Social Studies, Vol. 49 (2), pp.153-64.

Hallet, S. and Bishop, P. (1990), “Employment in estate agents: some evidence from South-west England”, Service Industries Journal, Vol.10, No. 3, pp.562-70.

Hambrick, D.C. (1983), “An empirical typology of mature industrial-product environments”, Academy of Management Journal, Vol. 26, pp.213-30.

Hawawini, G., Subramanian, V. and Verdin, P. (2003), “Is performance driven by industry- or firm-specific factors? A new look at the evidence”, Strategic Management Journal, 24(1), pp. 1-16.

Hodgkinson, J.D. (1997), “Cognitive inertia in a turbulent market: the case of UK residential estate agents”, Journal of Management Studies, Vol. 34, No. 6, pp. 921-45.

Hoskisson, R. E., Hitt, M. A., Wan, W. P. and Yiu, D. (1999), “Theory and research in strategic management: Swings of a pendulum”, Journal of Management, 25(3), pp. 417-456.

Lee, C., Lee, K. and Pennings, J. M. (2001), “Internal capabilities, external networks, and performance: A study on technology-based ventures”, Strategic Management Journal, 22(6/7), pp. 615-640.

Markides, C. C. (1999), “A dynamic view of strategy”, Sloan Management Review, 40(3), pp. 55-72.

McGahan, A.M. and Porter, M. E. (1997), "How much does industry matter, really?” Strategic Management Journal, 18(1), pp. 15-30.

McGahan, A. M. and Porter, M. E. (2002), "What do we know about variance in accounting profitability?”, Management Science, 48(7), pp. 834-851.

Maclennan, D. (1982), “Housing Economics”, Longmans, Harlow, Essex.

Maclennan, D. and Tu, Y. (1996), “Economic perspective on the structure of local housing systems”, Housing Studies, Vol. 11, No. 3, pp.387-406.

Maclennan, D., Munro, M. and Wood, G. (1987), “Housing choices and the structure of housing markets”, in Housing and Planning Research: Between State and Market (Edited by B. Turner and L. Lundquist). Almquist and Widesell International, Sweden.

Mansfield, E. (1979), “Microeconomics”, $3^{\text {rd }}$ ed., New York: Norton.

Mason, E. S. (1939), “Price and production policies of large scale enterprises”, American Economic Review, Supplement 29, pp. 61-74.

Mauri, A. J. and Michaels, M. P. (1998), “Firm and industry effects within strategic 
management: an empirical examination”, Strategic Management Journal 19, No. 3, pp. 211-219.

McGahan, A. M, and Porter, M. E. (1997), "How much does industry matter, really?” Strategic Management Journal, Summer Special Issue 18, pp. 1530.

McGahan, A. M, and Porter, M. E. (2002), "What do we know about variance in accounting profitability?” Management Science, 48(7), pp. 834-851.

Miceli, T.J., Pancak, K.A. and Sirmans, C.F. (2000), “Restructuring agency relationships in the real estate brokerage industry: an economic analysis”, Journal of Real Estate Research, Vol.1/2, pp.31-47.

Milbourne, P. (1999), “Changing operations? Building society and estate agency activities in rural housing markets”, Housing Studies, Vol.14, No.1, pp.21127.

Miller, D. (1986), “Configurations of strategy and structure: towards a synthesis”, Strategic Management Journal, Vol.7, pp. 233-49.

Montgomery, C. A. and Porter, M. E. (1991), "Strategy: Seeking and Securing Competitive Advantage”, Boston, MA: Harvard Business School Publishing. O’Farrell, P.N., Hitchens, D.N.M. and Moffat, L.A.R. (1993), “The competitive advantage of business service firms: a matched pairs analysis of the relationship between generic strategy and performance”, Service Industries Journal, Vol.13, No. 1, pp. 40-64.

Porter, M.E. (1998), “Competitive Strategy”, Free Press, New York.

Qian, G. and Li, L. (2003), "Profitability of small- and medium-sized enterprises in high-tech industries: the case of the biotechnology industry”, Strategic Management Journal, Vol. 24, No. 8, pp. 881-887.

Ross, S.C. (1993), "Using free market principles to improve organizational effectiveness: guidelines for managers”, International Journal of Management, Vol.10, No. 1, pp.66-73.

Rothenberg, J., Galster, G., Butler, R. and Ditkin, J. (1991), “The Maze of Urban Housing Markets”, University of Chicago Press, Chicago.

Rumelt, R. P. (1991), “How much does industry matter?” Strategic Management Journal, 12, No. 3, pp. 167-185.

Schmalensee, R. (1985), “Do markets differ much?” American Economic Review, 75(3), pp. 341-351. 
Seth, A. and Thomas, H. (1994), “Theories of the firm: Implications for strategy research”, Journal of Management Studies, 31, No. 2, pp. 165-191.

Shostack, G.L. (1997), “Breaking free from product marketing”, Journal of Marketing, Vol. 41, pp. 7-30.

Walker, O.C. Jr. and Ruekert, R. W. (1987), “Marketing's role in the implementation of business strategies: a critical review and conceptual framework”, Journal of Marketing, Vol. 51, pp. 15-33.

Wernerfelt, B. and Montgomery, C. A. (1988), “Tobin’s q and the importance of focus in firm performance”, American Economic Review, 78, No.1, pp. 246250.

Yamin, S., Gunasekaran, A. and Mavondo, F.T. (1999), "Relationship between generic strategies, competitive advantage and organizational performance: an empirical analysis”, Technovation, Vol. 19, pp. 507-518.

Zeithaml, V. A. (1981), “Consumer perceptions of price, quality and value, a meansend model and synthesis of evidence”, Journal of Marketing, Vol. 52, pp. 222. 